\title{
EGYPT AS THRESHOLD AND THE HERO IN FOCUS IN HELEN BY EURIPEDES
}

Lorena Lopes da Costa ${ }^{1}$

\begin{abstract}
This paper analyzes how Egypt, land where Euripides develops the version of the myth narrated in Helen (412 BC), updates Scheria, island where Odysseus redifines his return narrating his adventures in the Odyssey. In order to establish the affinities with the Phaeacians' island, the tragic poet appropriates the greek view of Egypt, in which wonder and mystery are the main aspects, and incorporates odyssean elements to the plot, which enables him to recreate a story in which the hero and the war are put into question.
\end{abstract}

Keywords

Egypt; Scheria; hero; war; threshold.

\section{Resumo}

O presente artigo tem como objeto a peça Helen de Eurípides, datada de 412 a. C., e busca apreender de que forma o Egito, terra onde se desenvolve a versão do mito narrada pelo poeta, atualiza a Esquéria, ilha em que Odisseu redefine seu retorno ao narrar suas aventuras na Odisseia. Para estabelecer as afinidades com a terra dos feácios, o poeta trágico apropria-se da visão grega do Egito, em que a admiração e o mistério são os aspectos principais, e incorpora elementos odisseicos ao enredo, o que lhe permite recriar uma história em que o herói e a guerra são postos em xeque.

\section{Palavras-chave}

Egito; Esquéria; herói; guerra; limiar.

\footnotetext{
1 Associate Professor, Federal University of Western Pará - Santarém, Brazil. email: lorenalopes85@gmail.com
} 
In the story that Euripides tells us in $412 \mathrm{BC}$, according to which the real Helen would have been sent to Egypt by Hera as a revenge, what would follow to Troy in her place was nothing more than an image. It is for this image, her $\varepsilon^{\prime \prime} \delta \omega \lambda \circ v$, that Achaeans and Trojans fight and suffer many ills throughout ten years of war, until the fire and the destruction of Ilium put an end to the conflict and start the returns.

That Helen, even isolated in Egypt during the conflict between Achaeans and Trojans, is aware of the ills of war and feels guilty because of them: "And many a life beside Scamander's streams perished for me" (Helen, 52-3). In the play, she hears of Teucer how deeply hated she is in Hellas. According to Ajax' brother, who arrives in Egypt after being expelled from the country, Helen is the most hated amongst all

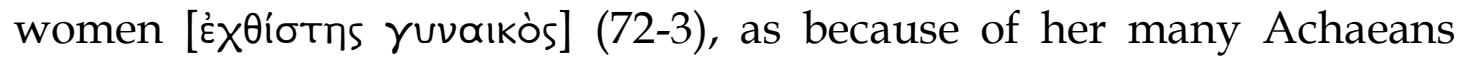

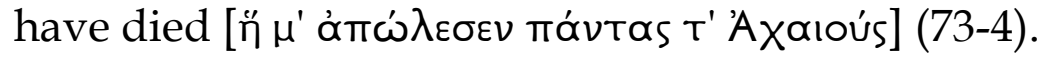

Euripides certainly was not the first of the Greeks to hate Helen and to love her as well, exploring the ambiguity of her character. ${ }^{2}$ Philosophers, sophists, poets debate about her. Overall, in tragedy the hatred for Helen is often replaced. Aeschylus, for example, despite some injuries, in the epithets given to her (Agamemnon, 687; 1454), doesn't talk about Helen as the most evil woman, but as a $\delta a i \mu \omega v$, a

\footnotetext{
2 Despite the controversy over the influence of epic and cult heroes (Van Wess, 2006), Helen is both worshipped in Lacedaemon and part of the race of heroes in Hesiod. In Works and Days (154-81), Helen, with Oedipus and Cadmus, is one of few individual members of the race of heroes. In Homer, we can see two attitudes towards Helen, namely hatred and admiration, mixed up. In the Iliad, there is no doubt that there are two kinds of feelings as well. Helen hears what the elders say about her (Iliad, III, 156). For Priam, not Helen, but the gods would be the cause of the war. But Iliad's Helen, in a moment of self-evaluation, says she would have preferred death than causing the war (Il., III, 173-6; III, 241-2; VI, 343-58; XXIV, 763-4). In the Cypria, the poet admits that Helen was the tool of a divine plan. And there are more references in the Epic Cycle about her. In Little Iliad, we are told that due to the death of Paris by Philoctetes arrows, Helen is betrothed by Deiphobus (216). In the Sack of Troy, we are told that Deiphobus is killed by Menelaus, who finally captures his wife (259-60). In the Odyssey, the ambiguity of Helen and her connection to war is even stronger. The faithful Eumaeus wishes the end of Helen's race because she had caused the death of many men (Od., XIV, 689). Odysseus also has harsh words for mourning the destruction caused by her and her sister, Clytemnestra (Od., XI, 436-7). She and Menelaus, back home, tell Telemachus two distinct versions of her participation in the war. Gorgias, Socrates, Plato (not only in Phaedrus and in Republic) discuss her behavior and her guilt. In poetry, Sappho (Fr. 166, 116) and Alceu (Fr. $42,283)$, before Euripides, emphasize the passion to drive Helen's behavior and in that passion they guess the divine intervention of Eros and Aphrodite. After them, Theocritus creates his Epithalamus of Helen, and Lycophron, in his Alexandra, takes back the idea of a ghost, presenting another variation to the story.
} 
divine power $(445 ; 799)$. In Euripides, Helen's conviction is repeated and declared in Andromache (426 BC), Hecuba (424), Trojan Women (415), Orestes (408), Iphigenia in Aulis (406). However, in Helen the poet seems to set aside the negative judgement to take the extreme ambiguity of the character to the edge. And he does so by choosing the version of the myth in which Helen goes to Egypt - for what the Epic Cycle and both the Iliad and the Odyssey show some tracks, although it is more evident in Herodotus (II, 113-20), where indeed there is a clear reference to the mistake of the Achaeans, though without any mention to Helen's duplicity.

The historian, there is no doubt, seeks for a rational explanation for the

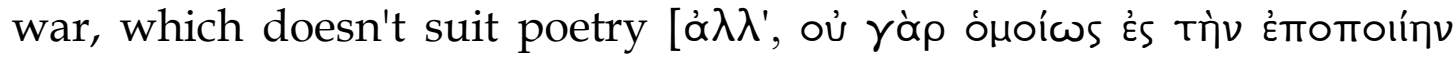

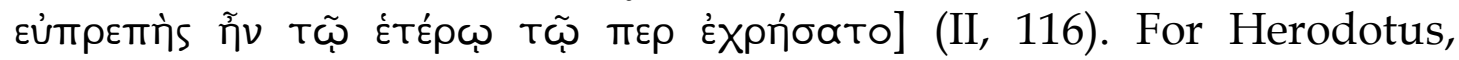
concerned with the historical chain of events, mistake has another nature. According to him, Paris, having kidnapped Helen and some treasures, tries to go back to his country, but the winds carry them to the Egyptian coast, where he is reported to the local forces. In that version, it is Proteus, king of Egypt, who takes charge of the issue and forbids Helen to go on with her captor. Proteus decides to keep both the woman and the treasures safe until the day that Menelaus would get them back. When that finally happens, he gives the son of Priam three days to leave his land 3 . Having been so welcomed by the kingdom of Proteus as his wife had been treated along ten years of war, Menelaus takes up his possessions and prepares his return to his country with his woman partner. However, they are blocked from leaving by bad weather. Seeking to appease the storm, he decides to sacrifice two Egyptian children. Then, he arouses the hatred of Egyptian people, by whom he starts to be pursued.

Herodotus chooses to include Egypt in the version adopted, but doesn't mention any ghost of Helen. According to a scholiast of Lycophron, Hesiod would have been the first to speak of it (822, scholium of Alexandra, by Lycophron), but it is Plato who puts on record the earliest allusion to Helen's duplicity, citing three verses by Stesichorus, poet from the sixth century $\mathrm{BC}$, whose fragment discovered in the twentieth century, preserved by the Oxyrhynchus Papyri number 2506,

\footnotetext{
${ }^{3}$ Before, the Achaeans send an embassy to Troy in order to take back Helen and the treasures taken by Paris. They are however refused, since neither Helen nor the treasures are there. Feeling they have been mocked, the Achaeans decide to declare war. They only seem to believe the sincerity of the Trojan answer when neither the defeat nor the destruction of Ilium seem to be enough to bring back Menelaus' wife. Only then does he leave Troy with his fleet to Egypt.
} 
proves the quotation by the philosopher (Woodbury, 1967; Beecroft, 2006).

"That saying is not true; thou didst not go within the well-oared ships, nor didst thou come to the walls of Troy."

(Phaedrus, 243 a 7 - b1, translated by H. N. Fowler)

In verses attributed by Plato to Stesichorus, Helen of Troy would not have existed; at least a Helen of flesh and blood would not have existed in Troy. She would not have gone to Troy and Troy would not have

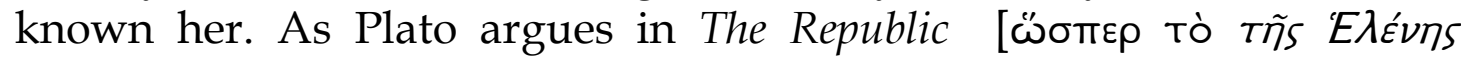

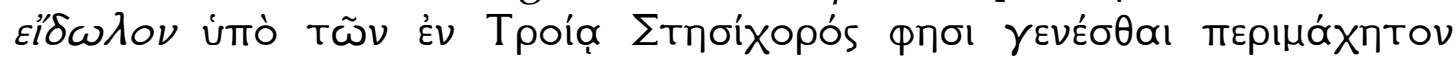

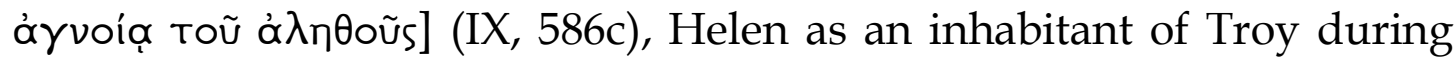
the years of war would not have been more than a $\varepsilon^{\prime} \delta \omega \lambda$ ov, an image, a simulacrum, a double, a ghost, a non-being, which, in spite of its empty existence, generates pleasure and hatred, makes men make war, and makes war, pleasure and hatred exist. Helen, in Stesichorus and Plato, therefore, would not have been more than a false image for what Greeks fight against Trojans for ignoring the truth.

Both the quotation from Plato and from Stesichorus' fragment have in common with Euripides the difference regarding the myth of Helen's kidnapping, as narrated by Homer. In Plato, also, the difference is enhanced with Stesichorus' life story. The creation of the Palinode, according to the philosopher, had served to the poet as an experience of purification as, having made a mistake in the mythology (the creation of myths) by narrating Helen's story inappropriately, Stesichorus would have been punished with blindness. The poet decides thus to apologize to the gods in order to recover from blindness by correctly narrating the myth. (Phaedrus, 243).

The tradition is full of stories of Helen and it is during the fifth century that they proliferate. The genealogy of the myth shows the popularity of the story and the character of Helen, especially in the fifth and fourth centuries, increasing the doubts around Euripides' choice by that less popular version, distinct from the other one narrated by Homer and whose meaning is different from that which guides the references to Helen in his other plays. It is true that already in Electra, which had been probably written before Helen, the poet refers to her eí $\delta \omega \lambda \circ v$, at the end of the play. Helen's brother announces, in accordance with what is narrated in $412 \mathrm{BC}$, that she had spent the years of war in Egypt, at the palace of Proteus, without ever having been to Troy.

Shall bury her, he and Helen: for she comes, 
Who ne'er saw Troy, from Proteus' halls in Egypt.

But Zeus, to stir up strife and slaughter of men,

A phantom Helen unto Ilium sent.

And Pylades shall take his virgin wife

And from the land Achaean lead her home

(Electra, 1280-1285, translated by Arthur S. Way)

Even if it is a brief reference, probably from 413 a. C., it already synthesizes the idea that Euripides develops in Helen. The Electra's Dioscuri allude to the argument of 412 BC: Zeus sends to Ilium not

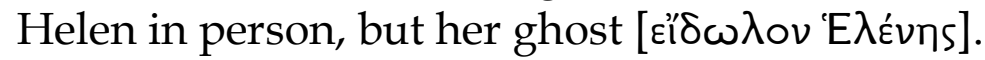

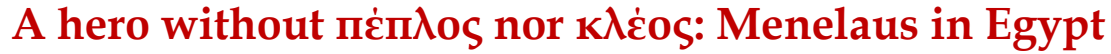

By choosing this version of the myth, according to which Helen of Troy was nothing but an image, Euripides makes the hero of the play, Menelaus, become a hero whose cause is no more than apparent. Like Odysseus, who only after spending some days in Scheria can go to Ithaca so as to complete his return from war, Menelaus must go to Egypt before returning to his land. There, in the kingdom of Proteus, he will recognize Helen and will realize that he had fought ten years for a ghost, for a cloud. Only then, after this double realization, will he be able to move from one world to another. After the mysterious journey at sea, like Odysseus, Menelaus arrives in Egypt without any mark that would allow him to be recognized. Once he is there, Menelaus acknowledges how fragile his condition is, how unrecognizable he is to the inhabitants of that foreign land:

\footnotetext{
I hide for shame my misery; for a man

Low-fallen from high estate more sharply feels

The strangeness of it than the long unblest.

Want wasteth me; for neither food have I

Nor raiment for my body, - judge by these

That gird me, rags washed shoreward from the ship.

The robes once mine, bright vest and bravery,

the sea hath swallowed.

(Helen, 417-24, translated by Arthur S. Way)
}

Menelaus arrives in Egypt in complete shabbiness, lacking any identity marks or glory he had earned during the war. To the servant, who is the first person he sees on Egyptian land, he says: "Ah me! - where now my glorious war-array? (Helen, 453). Menelaus sees the contrast between his glorious past as a warrior and his situation of total lack - not because he cannot handle wreckness, physical pain or hunger; the hero can handle the most difficult conditions (actually, he proves to be a hero as his 
body and limits are challenged). What seems to be difficult to Menelaus, therefore, are the requirements of the return, a kind of stage in the constitution of the hero, who, not having died in the war, might or might not be recognized as a hero in his lifetime. ${ }^{4}$ Menelaus comes to the foreign land knowing that he is not the same as he had been in the war: the pride remains "for those my happy fortunes overpast" (Helen, 457), 5 but there is no more ship nor pomp and his worth is not acknowledged by others. After the shipwreck, having lost everything, he becomes no more than a common, even if he was once a great war hero. It is in this state that he becomes able to understand the kind of warrior he was in Troy. When he arrives in Egypt, Menelaus is proud of his achievements in war, but in spite of that, aware of the suffering he caused:

And me, Menelaus, chariot-team renowned.

The mightiest host on earth - no mere vaunt this -

Did I speed overseas to Troy, their chief;

Nor by compulsion captained them to war,

But led with Hellas' heroes' glad consent.

some must we count mid them that are no more;

Gladly have other some escaped the sea,

And bring back home the name ode men deemed dead

But I far o'er the grey sea's shoreless surge

Wander in pain, long as the leaguer-years

Of Troy; and though I yearn to reach my land,

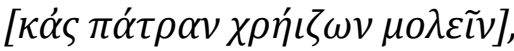

Of this I am not held worthy by the Gods,

But to all Libya's beaches lone and wild

Have sailed: yea, whenso I am nigh my land,

Back the blast drives me; never following breeze

Hath swelles my sail to waft me to mine home

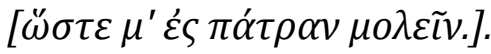

And now, a shipwrecked wretch, my comrades lost,

On this land am I cast: against the rocks

My ship is shattered all in countless shards.

(Helen, 392-410)

\footnotetext{
${ }^{4}$ It is not Tragedy that decides who returns and who does not return to homeland after the Trojan War. These choices are made by a myth prior to the tragedy. The Epic Cycle, the Iliad, the Odyssey, already state the heroes who die in the Trojan War, those die in the return and those who come back home alive. But the theatre gives its own touch to the connection between the way of the return (or the way of the impediment of the return) and the war.

5 The comic value of the scene is generally presented, in which the servant asks the shipwrecked why he cries, obtaining the following answer: "for those my happy fortunes overpast" (Helen, 457). What seems to be a funny assertion opposes Menelaus' pride to the adversity of the situation.
} 
Before understanding that the war had been caused by a cloud, he keeps stating his glory, acknowledging the evil combat, but not the inconsistency of its source, as he says to Helen: "My toils at Troy convince me more than thou" (Helen, 593). Menelaus is therefore a focus of the poet's cruel irony, as are all those who fought at his side: they have fought for nothing. Only in Egypt, after the war, will Menelaus find out about failure, realizing that his glory, at least in Egypt, is insipid: "Wander in pain, long as the leaguer-years of Troy; and though I yearn to reach my land, of this I am not held worthy by the Gods" (Helen, 403-5).

\section{The Egypt of Euripides as a threshold between war and homeland}

From the first lines of the play, the audience is informed that Helen is in Egypt, country per excellence where real and unreal are mixed, evoking, in that sense, the Odyssey and the land of Alcinous, where the hero must recognize himself and be recognized so as to finally return to his homeland at the end of the war. That coming and going between those two worlds points to the coming and going between illusion and truth, between the name and the thing, the picture and the being: the challenge of the play. On the one hand, there is the real world, represented realistically for both the war of many sufferings and the fatherland; on the other hand, there is the wonderful world of Egypt, presented in a picturesque and fabulous way, where magic is possible, dangers are many and truths are shaken. The poet asks, through the image of Helen, how to recognize what is true and what is false, how to discern between them. She and Menelaus will need to answer these questions, even if not totally, in order to cross the picturesque and fabulous world and fulfill the journey that connects the war to the homeland.

In the play, Egypt corresponds to the beauty and the ambiguity of Helen, as indicated by the description made by Teucer, before Menelaus, when he arrives there (Helen, 68-70). Egypt is the exact opposite of Troy: there, Helen's beauty and loyalty can be kept intact, although, beside the mythical and benevolent image of Proteus and the virgin Theonoe, who both shelter the guest, is the violent Theoclymenus. But, in the Euripidean Egypt, parallely to the wealth, beauty and fidelity, there are constant threats of violence and infidelity. This ambiguous Egypt by Euripides is certainly a Hellenized Egypt. The Egyptian characters are Greek by name, speak Greek and their deities are Greek as well. Theonoe worships the Olympic gods and knows no other but them. Nevertheless Hellenized in part, Egypt is for the 
audience a mix, in the same image, of the admirable otherness of that ancient civilization (of which Herodotus tells us) and derision and mockery, despite its history. Theoclymenus, the cruel king, son of the generous Proteus, shows with his cruelty a clear confirmation of common sense about Egypt, as his figure is not a marginal figure in the Greek view of Egyptian kings. Herodotus and Diodorus tell us that Prometheus, the hospitable king, is the exception among the Egyptian kings, who are generally xenophobic and violent. We are told that sovereign Egyptians before Psammetico had forbidden the access of foreigners to their land, killing or enslaving those who, despite the ban, managed to reach their land. This legend, according to Diodorus, would have generated the fame of Egyptian xenophobia (Diodoro, I, 67).

For that matter, the king's cruelty preserves in the play something of the Egyptian way into the public eye. The rule is indeed that the hospitality yields to arbitrary violence. The lords of that palace, reports the servant (the one who first sees the shipwrecked Menelaus), are not related with the Greeks and whoever might be the Greek approaching, he will die (Helen, 439-40), because Theoclymenus, Proteus' son, is his

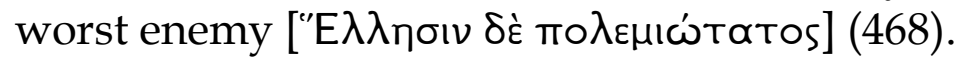

\footnotetext{
Thou art come in evil hour, and if my lord Find thee, thy stranger's welcome shall be death.

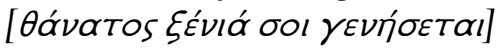
Well-wisher unto Greeks am I, although Harsh words I gave for terror of my lord. (Helen, 479-82)
}

Egypt, according to the poet, has one single rule when it comes to hosting their guests, at least the Greeks: they ought to be killed. There, hospitality is the equivalent of murder. However, although this is the official guidance, not all hosts follow the rule. This Egypt of Euripides, in this regard, is and is not related to the Egypt of Herodotus, with whom the Greeks learned about the Egypt of other times. The servant, the first to report the risk to the foreign man, is also the first to protect him. As it happens with Odysseus when he reaches Scheria, Menelaus is the shipwrecked without his king's robes, without protection, without knowing where he is, face to face, before meeting the Egyptian men, with the women from there. From the servant and Helen, Menelaus finds out what kind of host he will find: "Alas, toil-tried, thou nam'st a weary space!/ Yet, thence escaped, thou meetest murder here" (Helen, 777778), says Helen to his husband. Odysseus, albeit less explicitly, takes some risk being foreign in Scheria. Indeed, the non association of the 
Phaeacians with other people, their insularity (Villate, 1991), ${ }^{6}$ their nonhospitality, are suggested, for example, when Nausicaa asks him to go alone towards his father's palace, since the countryman could defame

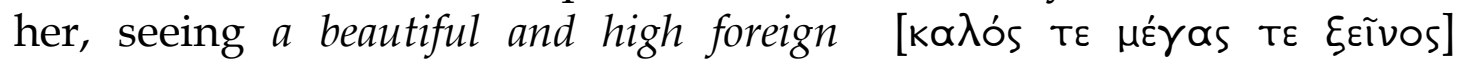
(Odisseia, VI, 276-7) beside her, since:

"(...) But turn not thine eyes upon any man nor question any, for the men here endure not stranger-folk, nor do they give kindly welcome to him who comes from another land. They, indeed, trusting in the speed of their swift ships, cross over the great gulf of the sea, for this the Earth-shaker has granted them; and their ships are swift as a bird on the wing or as a thought." (Odyssey, VII, 31-36, translated by A. T. Murray)

These Phaeacians, people without neighbours, unassociated with other people, keep, however, not an unrestrained hostility to foreigners which would inevitably threaten Odysseus' return to his country, as the speech of Nausicaa suggests - but an uncertainty on the issue, which could end up as something positive for the foreign man, according to his behavior. Gilbert Rose (1969) argues that, contrarily to the common opinion on the good hospitality of the Phaeacians, they receive the hero with suspicion and distrust. However, they gradually welcome him more warmly, so that Odysseus wins the loyalty of a people who is far from being ready to offer the stranger a paradise in which hostility and fear inexist. ${ }^{7}$

In Helen, Theoclymenus, being unfriendly towards foreigners as well, with the arrival of the wrecked (Menelaus disguised) bringing positive news (the death of Menelaus at sea), only acts as the hospitality rules order due to the fake Helen's mourning and due to the expectation that finally he could marry her (all going according to Helen's plan). Thus the declared hostility towards the Greeks gives place to good news. The

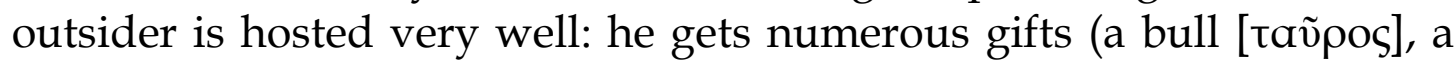

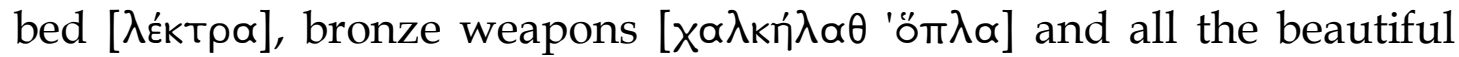

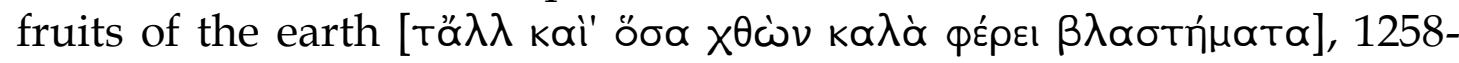
1265). He tells his story, takes a shower and puts on a new robe. After all, he will return to his homeland, against Theoclymenus' expectations, with what belongs to him (besides the gifts received, his wife, Helen), through which belongs to the Egyptian king (a boat and the rowers). Indeed, Theoclymenus, as Alcinous, ensures his guest the return:

\footnotetext{
${ }^{6}$ There is not a notion of insularity and a term for it in Homer, but only island, nêsos.

7 Gilbert Rose's view is opposite to a tradition that identifies the Phaeacians as hospitable people, and his land as a kind of paradise. In this tradition, stand out names such as: Charles Segall, C.H. Whitman, G. Lord and Combellack.
} 
Let her go: - best to foster in my wife

Piety. From mine halls the death-dues take.

Nor thee will I send empty-handed hence,

For this thy kindness shown her. For good news

Thou hast brought me, raiment in thy bare rags' stead

And food shalt thou have, so that thou mayst come

To Greece, whom now I see in sorriest plight.

(Helen, 1278-84)

The description of the gifts shows not only the good and unprecedented hospitality of Theoclymenus - an Egyptian pharaoh being a good host to a Greek - but the abundance and wealth of their land. For that matter, in a scene where several elements evoke the arrival of Odysseus to Scheria, it is unlikely that the mention of the good land of Egypt has not evoked the plentiful bed of Alcinous, where "ever does the west wind, as it blows, quicken to life some fruits, and ripen others; pear upon pear waxes ripe, apple upon apple, cluster upon cluster, and fig upon fig" (Odyssey, VII, 11421).

The Phaeacians' island, both a geographic and psychological threshold between two worlds (Reece, 1993), is the very place where Odysseus' nóstos is defined in the Odyssey, not because it will begin or end there, but because that is where it will become possible. Scheria is both the boundary between the real world and the fabulous world (VidalNaquet, 1970), as the boundary between two different areas of experience: the Trojan war and the kingdom of Ithaca. It is there that Odysseus realizes that in order to actually return to his homeland, he must acknowledge its past, thus recognizing himself. For Charles Segal (1994), by the way, Odysseus' return should be thought not exactly in the sense of Vidal-Naquet (1970), as a rescue of his humanity, but, more specifically, as a return to mortality. It is in order to realize his mortality that Odysseus needs to hear and narrate his experiences from a kind of inhuman past, thus immortal (immortalized by Demodocus singing): "and Odysseus' review of the totality of his experiences in the unreal world occurs in the very shadow of his return to reality: only one eagerly awaited dawn separates the two worlds" (Segal, 1994: 19), the real one, to which he tries to return, and the unreal, which he tries to escape.

Of all the elements that bring closer the Scheria of Egypt, the strongest is precisely the recognition as proof to be overcome for the fulfillment of the return. Both Helen and Menelaus experience this proof in Egypt and only then will they be able to return to their homeland, making of Egypt still more of a boundary land between the experience of war and the return, two worlds. There, Menelaus and Helen will recognize each 
other, but above all, as it happens to Odysseus, each of them will be able to recognize themselves. Each one will acknowledge their past: Menelaus will be acknowledged as the warrior of a war empty of reason and Helen as being guilty of a war whose terrible images arrive with foreigners in Egypt (Menelaus, his servant and Teucer). For the first time in ten years of war and seven of wandering, Menelaus remembers the war sufferings and faces over the issues that the real story of Helen adds to his war experience.

In Scheria, Odysseus tastes the misery of goods and fame, but gets them back while he tells his stories. In Egypt, Menelaus has a similar process: if when he arrives he is an unknown, without army or glory, on his way out he takes up his army with whom he had defeated Ilium and retrieves his heroic excellence. Above all, he manages to revitalize war legitimacy by capturing the true Helen. It is precisely in order to update war glory that Helen asks in the final fight: "Where is your Trojan fame?"

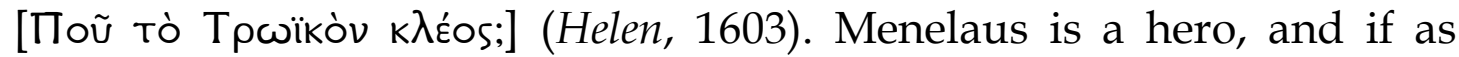
Odysseus he may return to his homeland after crossing the threshold between two worlds, unlike Odysseus he can only move from one world to the other if he makes war again 8 .

\section{New war in Egypt or Menelaus' coward war: updating of the glory or deconstruction of the hero?}

Even if according to the message of the chorus the war is worthless and if Helen is able to imagine its horrors (38-9, 109, 196-210, 362-74, 383-5), she, however, does not hesitate to urge the use of violence in order to achieve her goal. It is Helen who prepares the battle plan in the sea, and she is the one who prepares Menelaus to fight by dressing him [ $\varepsilon \gamma \omega$ viv

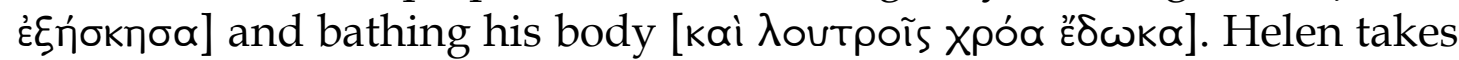
part in his rebirth for the clash with the Egyptians, which will update the Trojan War and give a real reason to the new war.

As Helen's plan worked well (escaping from Theoclymenus' castle by saying they would only pay homage to Menelaus and return afterwards), after immolating the bull already at sea, Atreus' son calls

\footnotetext{
8 It is true that to return home, Odysseus will need to obtain coonsent from their Phaeacians hosts and that consent will be the result of some indirect confrontations, since the son of Laertes is target of suspicion of Alcinous' people, having being insulted by Euryalus (Od., VIII, 140-164). But in Scheria, there is no direct confrontation close to what happens in Egypt in the Euripides' play. Or, in this case, should we consider that Odysseus also makes war by killing the suitors in Ithaca, for, just then, returning to his home?
} 
his companions for the final battle: "Wherefore delay, O flower of Hellasland/, to smite, to slay the aliens, and to hurl/ into the sea?" (1593-5). Helen encourages them: "Where is your Trojan fame?/ Show it against the aliens" (1603-4). At that time, she is definitely on the Greek side against the enemies, and neither Helen nor Menelaus seem to refer to the Trojan War ambiguously. Instead, the Trojan glory is remembered proudly, in clear reference to the heroic code. Menelaus says: "I will not shame the glory achieved at Troy" (845).

It is true that the idea of a sacrifice that allows the return is not Euripides' innovation. In the Odyssey, the price that the Phaeacians pay for carrying Odysseus is the petrification of the ship used to bring him to Ithaca. According to Herodotus, Menelaus, in order to leave Egypt, sacrifices two children there in order to make the winds blow in his favour (Herodotus, II, 119). But the final battle in Helen changes the sacrifice into barbarism, updating the glorious past in a very particular way.

The connection between the war and the return is not the same for everyone in the play. If for Helen and Menelaus it is necessary to recover the glory in the war, testing its ability to be updated, for the chorus, the others characters and the play as a whole seem to repeat to Helen the question she asks the arm: "Where is your Trojan fame?" [Поũ

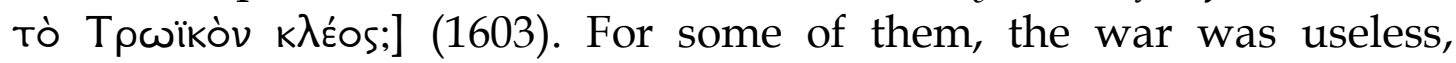
deplorable, so that even the glory of the greatest warriors had turned into useless and deplorable glory. Teucer, without even knowing the history of Helen's eidōlon, is one of those. The war, made for the rescue of Helen and the honour of Menelaus, ends up with his brother's suicide and his own exile from Salamis. After collaborating in the destruction of Ilium, he gets lost (106). Teucer talks about himself as a victim and not as a war hero; he condemns the war by refusing his heroic condition (Helen, 72-7, 81, 162-3), without being able to distinguish between winners and losers: "Yea, helped to smite her - and myself was stricken" (Helen, 106).

Euripides provides a sharp contrast between the fate of the heroes and the fate of the anonymous warriors, since the Trojan War, carried out by an empty purpose, an eidōlon, kills thousands of Greeks and Trojans in Ilium, "yea, of her walls no trace may be discerned" (Helen, 108), while for Helen and Menelaus the gods give a happy ending with the return to the homeland. From the prologue, everything has been prepared to put in evidence the discrepancy between the hero (who proves to be a coward at the end of the play) and the best among the best of Hellas 


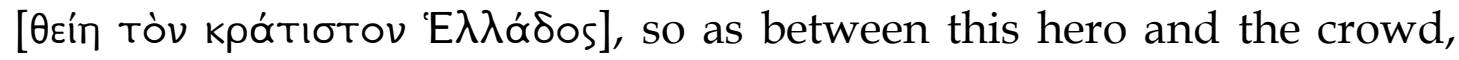
the large crowd of mortals [öx $\lambda$ ou $\beta$ pot $\tilde{\omega} \nu \pi \lambda \eta \dot{\theta}$ ous].

The war is still to be seen as a mean of acquiring heroic glory and as the solution to ills, despite the chorus verses: it is not by chance that Helen, Menelaus and his crew will return to Hellas. On the other hand, there is a total condemnation of the Trojan War as a useless and overwhelming enterprise; condemnation from Teucer, from the anonymous warriors who had gone to war without becoming heroes, and from the messenger, who tells Menelaus: "I say thou barest toils untold for naught" (603); or asks after learning what had happened: "For a cloud then all vainly did we strive?" (706). There indeed, when the messenger meets Menelaus and consequently meets Helen, is one of the many scenes of recognition (Kannicht, 1969). Recognizing Helen, the messenger acknowledges therefore the futility of war and personifies the whole mass of anonymous warriors whose lives were ruined by war. The messenger's reaction, so different from Menelaus' reaction, helps realizing how much the hero is suffering, which will be rewarded contrarily to the crowd, who suffers and is not rewarded for so:

\author{
This will I do, King. But he lore of seers, \\ How vain it is I see, how full of lies. \\ Utterly naught then were the altar-flames, \\ The voices of winged things! Sheer folly this \\ Even to dream that birds may help mankind. \\ Calchas told not, nor gave sign to the host, \\ Yet saw, when for a cloud's sake died his friends: \\ Nor Helenus told; but Troy for nought was stormed! \\ "Yea, for the God forbade," thou mightest say. \\ Why seek we then to seers? With sacrifice \\ To Gods, ask blessings: let soothsayins be \\ They were but as a bait for greed devised: \\ No sluggard getteth wealth through divination. \\ Sound wit, with prudence, is the seer of seers. \\ (Helen, 744-57)
}

\begin{abstract}
Also the final battle puts into question the glory of the heroes and the innocents, bringing out the first and erasing, as usual, the second. The ferocity of the battle won by Menelaus against their unarmed enemies perfectly suits his Iliad's nature of brute strength, and serving to the poet's irony of which he is victim: Menelaus takes up his glory

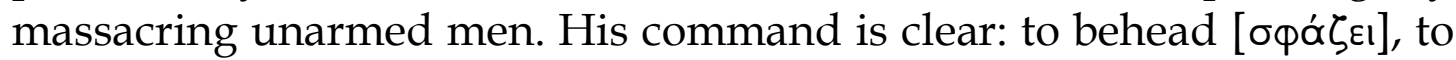

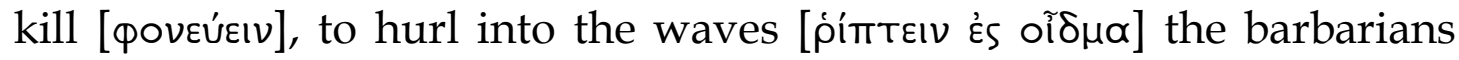

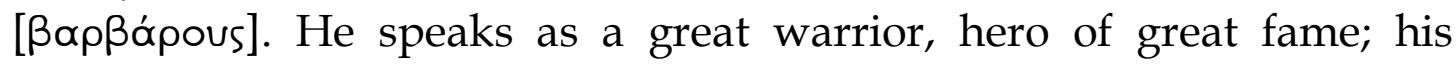


action, however, is anything but heroic. Menelaus is a coward and the detailed description of the event emphasizes his cowardice.

\author{
"Wherefore delay, O flower oh Hellas-land, \\ To smite, to slay the aliens, and to hurl \\ Into the sea?" The to thy sailor cried \\ The boastwain - overaganist him his command \\ "Ho, catch up, some, what spar shall be to hand, \\ Some break up thwarts, some snatch from thole the oar \\ And dash with blodd the alien toemen's heads!" \\ Up started all, these grasping in their hands \\ The punt-poles of the ship, and those their swords; \\ Ans all the ship ran blood. Then Helen's cry \\ Rang from the stern - "Where is your Trojan fame?" \\ Show it against the aliens! "Furious-grappling \\ Men fell, - men struggles up, - some hadst thou seen \\ Laid dead. But Menelaus all in mail, \\ Marking where'er his helpers were hard pressed, \\ Thither in right hand ever bore his sword, \\ That from the ship we dived, and of thy men \\ He swept the thwarts: and, striding to the hilm, \\ He bade the helmsman steer the ship for Greece.
} (Helen, 1593-1611)

The scene is, to put in Verrall's words, intolerable: "[it] would be repulsive if it were not too silly" (Verral, 1905: 54). How to find ridiculous, however, a scene in which war is the solution to return when the chorus had already warned: "Madmen, all ye who strive for manhood's guerdons/ Battling with shock of lances, seeking ease/ Senselessly so from galling of life's burdens!" (1151-1153)? Would the poet not be _staging the insistence on war as the way to solve a problem? Would there not be condemnation of the war itself but, more than that, a suggestion that warriors, as Menelaus, and even anonymous people, could not define their destinies but through war?

According to Karl Reinhardt (1972), Euripides presents a clear crisis of sense in the ancient world. His play is a place for doubt and loss of sense. This crisis of sense that characterizes Euripidean tragedy is an instrument to measure the same crisis of sense that marks the end of the fifth century BC in Athens. The poet puts in scene not only battles as illusions and paradoxes of the mind: the human soul appears in its ambiguity, in its weakness, in movement and fear, as it is now expatriated of the gods' universe, to which it was once submitted.

That Euripidean world, realm of vengeance and punishment, is not the world of justice and processes but of war and cruelty, in which moral certainties are shaken by the war - in part a real world in Athens of 412 
BC, in part only an eídōlon (Saïd, 1978). After nearly twenty years of war against Sparta and the recent disaster in Sicily, when people seek for the meaning of war, it is the myth of Helen, the war subject per excellence, which Euripides picks up to propose his reflection. Actually, this move is not unprecedented. Around 420 BC, Gorgias, in his Encomiun of Helen, investigates Helen in order to explore the limits of speech. The sophist

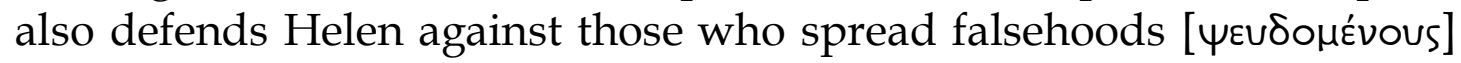
about her. Nearly twenty years after, in answer to what Gorgias had written, Isocrates says: "we should be justified in considering that it is owing to Helen [EXÉvnv aitíav Eĩval] that we are not the slaves of the barbarians" (Isocrates, 67, translated by Larue Van Hook).

The language, the plot and the form of Euripides' Helen express the tension between what really is and what seems to be. All the characters in the play suffer from some inability to grasp the truth (all but Theonoe, who has a special understanding and vision). The chorus expresses its idea of truth and falsehood, as do Menelaus and his servant. Helen, more than anyone, knows how to manipulate words, draws on the appearance. She teaches Menelaus how to lie (Helen, 104984). Indeed, her skills of imitation and counterfeiting are presented very early in the tradition since, in the Odyssey, she imitates the voices of the Achaean's wives in order to get them confused (Od., IV, 277). Helen is, finally, a play about pretending, falsehood, deceit, mistake, deception, which are, nevertheless, full of intentions and power.

\section{Concluding remarks: Egypt as a new Scheria?}

From very early texts, the Phaeacians' island is chosen by tradition as the place, per excellence, for the discussion of truth and falsehood. Among them, there are those who see in the hero's adventures a purely fantastic narrative and thus mendacious (Goldhill, 1991). It is at that island that the stories lived by Odysseus are told in the first person'. Therefore, only in Scheria can people listen to the stories of ten years of wandering told by Odysseus himself. In addition, these stories remain in the Odyssey somehow preserved in Scheria, since the way from that island to Ithaca will be kept unknown to mortals. After all, Odysseus, the one who could reveal it, was hit, at the time the ship left, by a "sweer

\footnotetext{
${ }^{9}$ Even if alluded again, after a night with Penelope, the stories told by Odysseus to the Phaeacians are, during this second time, narrated by the poet, not by Odysseus: "he began by

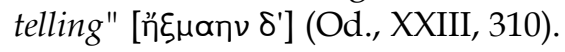


sleep [that] fell upon his eyelids, an unawakening sleep, most sweet, and most like to death" (Od., XIII, 80), and remained asleep all the way back home.

In the Odyssey, the Odysseus' stay at the Phaeacians' island can be thought in terms of a journey that takes him to an inaccessible place, where a true temporal suspension reigns (Brandão, 2010). Scheria is a world of transition between the savagery of Odysseus' adventures and the human world to where he wants to return, Ithaca (Goldhill, 1991). After Troy, according to Odyssey, Scheria is the only city of men seen by Odysseus until he returns to his homeland. It is there that Odysseus, printing a significant narrative change, tells what he had lived from Troy to Ogygia, from where he leaves to go to Alcinous' kingdom. There, at last, Odysseus "transforms his experience in narrative and, consequently, also in knowledge" (Brandão, 2010: 18). In the narrative, Odysseus confirms himself as hero, handling what had happened and narrating what had happened. After visiting Scheria and being hosted by the Phaeacians, Odysseus finds a place to some extent concealed from the human experience (one cannot be sure of the extent of the concealment until his arrival, but things become clearer after he leaves). With the punishment of Poseidon to the Phaeacians - the petrified ship , Odysseus becomes, if not the only, at least the last man who was both able to visit the remote land and be transported by the friends of oars. Also the Phaecians' ships suggest Scheria's uchronia, in the literal sense of no time, accentuating uncertainty about the location and the existence of the island. The speed with which they cross the abyss of the sea points to a temporality inaccessible to mortal men. And Odysseus' sleep during his trip to Ithaca can only strengthen, for the narrative receiver, the idea that Scheria would be difficult to discover - in time and space - or so hidden in the ends of the earth that would be inaccessible and thus preserved in the memory of Odysseus as a souvenir, but not as a place to return.

In Helen from 412 BC, Euripides seems to have chosen Egypt as a kind of Scheria's survey because there the return of the hero and his wife are defined. It is also there that everything he had done over the past few years, since the beginning of the Achaean expedition to Troy, is called into question. Above all, it is there that as Odysseus narrates his deeds to the Phaeacians, recognizing them, Menelaus will also recognize his deeds, but, unlike Laertes' son, who confirms to be the very hero, Menelaus makes of his cowardice his warrior vocation. As it happens to Scheria in the Odyssey, the Egypt in Helen, being a threshold between two worlds - the world of truth and the world of falsehood, or the world of truth and the world of falsity - is all about fluidity between 
these two values, truth and falsity or truth and falsehood, in order to update the myth. By choosing Stesichorus' version, alluded to by Plato, Euripides appropriates a vision of Egypt, already known in the tradition, to elaborate the worries of his play and his world. The poetic strategy of Euripides seems to invoke the falsehood, the false, the negative myth, that is myth as well, for asking the reality what was not asked through the most common narratives about Helen. Euripides, in order to talk about war (and Athens was at war!), what it does and the real suffering it brings to men, their men and not their heroes, will need not to point to war but to its lies, its falsity. In the play, one can see the false as a value transformed into a narrative construct; as synthesizes

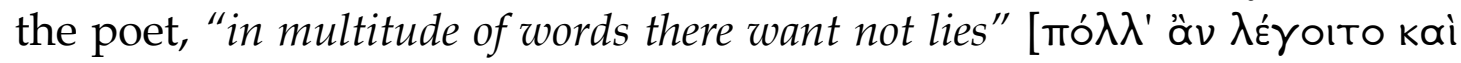

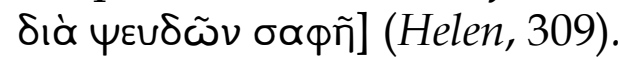

\section{Sources}

DIODORE DE SICILE. Bibliothèque Historique. Texte établi par Pierre Bertrac et traduit par Yvonne Vernière. Paris: Les Belles Lettres, 1993.

EURIPIDE. Hélène. Texte établi et traduit par Henri Grégoire. Introduction et notes par Françoise Frazier. Paris: Les Belles Lettres, 2007.

EURIPIDES. Iphigeneia at Aulis, Rhesus, Hecuba, The Daughters of Troy, Helen. With an English translation by Arthur S. Way. London: William Heinemann. New York: G. P. Putnam's Sons, 1916.

EURIPIDES. Electra, Orestes, Iphigeneia in Taurida, Andromache, Cyclops. With an English translation by Arthur S. Way. London: William Heinemann. New York: The Macmillan Co, 1912.

EURÍPIDES. As Troianas. Introdução tradução do grego e notas de Maria Helen da Rocha Pereira. Lisboa: Edições 70, 2014.

EURÍPIDES. Duas tragédias gregas: Hécuba e Troianas. Tradução e introdução Christian Werner. São Paulo : Martins Fontes, 2004.

EURÍPIDES. Electra. Trupersa. Trupe de tradução de teatro antigo. Direção de tradução de Tereza Virgínia Ribeiro Barbosa. Cotia: Ateliê Editorial, 2015.

EURÍPIDES. Helen. Versão do grego, introdução e notas José Ribeiro Ferreira. Porto Alegre: Movimento, Instituto de Estudos Clássicos da 
Faculdade de Letras da Universidade de Coimbra, 2009.

EURÍPIDES. Orestes. Introdução, tradução e notas de Augusta Fernanda de Oliveira e Silva. Textos Clássicos - 13. Coimbra: C.E.C.H, 1982.

Euripidis fabulae, vol. 2, Ed. J. Diggle. Oxford: Clarendon Press, 1981; 1994.

Euripidis fabulae, vol. 3, Ed. J. Diggle. Oxford: Clarendon Press, 1994.

GORGIA. Encomio di Elena. Testo critico, introduzione, traduzione e note a cura di Francesco Donadi. Roma: L'Erma di Bretschneider, 1982.

HÉRODOTE. Histoires, 9 vols, Ed. Legrand, Ph.-E. Paris: Les Belles Lettres, 1932; 1968.

HERÓDOTO. História. Tradução do grego, Introdução e Nots de Mário da Gama Kury. Editora Universidade de Brasília, 1985.

HESIOD. Theogony. Ed. West, M.L. Oxford: Clarendon Press, 1966.

HESÍODO. Teogonia: a origem dos deuses. Estudo e tradução de Jaa Torrano. São Paulo: Iluminuras, 2007.

HOMER. Odyssey - I. With an English translation by A. T. Murray. Cambridge: Harvard University Press. London: William Heinemann Ltda, 1955.

HOMER. Odyssey - II. With an English translation by A. T. Murray. London: William Heinemann Ltda. New York: G. P. Putnam's Sons, 1919.

Homeri Ilias, vols. 2-3, Ed. Allen, T.W. Oxford: Clarendon Press, 1931.sEPE:

Homeri Odyssea, Ed. Peter von der Mühll, P. Basel: Helbing \& Lichtenhahn, 1962.

HOMERO. Ilíada. Tradução de Frederico Lourenço.São Paulo: Penguin Classics; Companhia das Letras, 2013.

HOMERO. Odisseia. Tradução de Frederico Lourenço. São Paulo: Penguin Classics; Companhia das Letras, 2011.

ISOCRATE. Discours. Tome I. Texte établi et traduit par Georges Mathieu et Émile Brémond. Paris: Les Belles Lettres, 1972. 
ISOCRATES. Orations - III. With an English translation by Larue Van Hook. Cambridge: Harvard University Press. London: William Heinemann Ltda, 1945.

Lycophronis Alexandra, vol. 2, Ed. Scheer, E. Berlin: Weidmann, 1958.

PLATÃO. Fedro. Texto grego John Burnet; tradução Carlos Alberto Nunes. 3. ed. Belém: ed. ufpa, 2011.

PLATO. Euthyphro, Apology, Crito, Phaedo, Phaedrus. With an English translation by H. N. Flower and an introduction by W. R. M. Lamb. London: William Heinemann. New York: The Macmillan Co, 1913.

PLATON. Fédre. Tome IV - 3e Partie. Texte établi par Claudio Moreschini et traduit par Paul Vicaire. Paris: Les Belles Lettres, 1994.

Platonis opera, vol. 2, Ed. Burnet, J. Oxford: Clarendon Press, 1901, Repr. 1967.

PROCLUS. Chrestomathia. Recherches sur la Chrestomathie de Proclus, vol. 4, Ed. Severyns, A. Paris: Les Belles Lettres, 1963.

PROCLUS. Greek epic fragments: from the seventh to the fifth centuries BC. Martin L. West (edition and translation). Cambridge, Mass.; London: Harvard University Press, 2003.

STESICHORUS. The poems. Edit. and transl. M. Davies and P. J. Finglass. Cambridge University Press, 2015.

\section{Bibliography}

BEECROFT, Alexander. This is not a true story: Stesichorus's Palinode and the Revenge of the Epichoric. Transactions of the American Philological Association, Volume 136, Number 1, Spring 2006, p. 47-70.

BRANDÃO, Jacyntho Lins. A experiência de Ulisses: nota sobre um tema utópico perdido. Revista Morus - Utopia e Renascimento 7. Dossiê "Utopia e viagem. Tão longe, tão perto". 2010, p. 15-26.

COELHO, Maria Cecília. Eurípides, Helen e a Demarcação entre Retórica e Filosofia. 2002. Tese (Doutorado em Letras Clássicas). Universidade de São Paulo, USP, Brasil. 2002. 
GOLDHILL, Simon. The poet's voice: Essays on poetics and Greek literature. Cambridge: Cambridge Univ. Press, 1991.

GOOSSENS, Roger. L'Égypte dans l'Hélène d'Euripide. Égypte Pharaonique. Chronique 20, juillet 1935, p. 243-53.

KANNICHT, R. Euripides, Helen. Heidelberg: Winter, 1969.

MELTZER, Gary S. Where Is the Glory of Troy? Kleos in Euripides' "Helen". Classical Antiquity, Vol. 13, No. 2 (Oct., 1994), p. 234-55.

MOERBECK, Guilherme Gomes. O pensamento de Eurípedes e a política durante a Guerra do Peloponeso. 2013. 242 f. Tese (Doutorado em História). Instituto de Ciências Humanas e Filosofia, Universidade Federal Fluminense, Rio de Janeiro. 2013.

REECE, Steve. The Stranger's Welcome: Oral Theory and the Aesthetics of the Homeric Hospitality Scene. Michigan Monographs in Classical Antiquity. Ann Arbor: University of Michigan, 1993.

REINHARDT, Karl. La crise du sens chez Euripide (1958). In: REINHARDT, Karl. Eschyle; Euripide. Trad. par Emmanuel Martineau. Paris, Gallimard, 1972.

ROSE, Gilbert. "The Unfriendly Phaeacians". Transactions and Proceedings of the American Philological Association. Vol. 100, (1969), p. 387-406.

SAIID, Suzanne. Euripide ou la critique de la responsabilité mythique. In: SAÏD, Suzanne. La faute tragique. Paris: Librairie François Maspero, 1978.

SEGAL, Charles. Singers, Heroes, and Gods in the Odyssey. Ithaca; London: Cornell University Press, 1994.

VAN WEES, H. From kings to demigods: epic heroes and social change c. 750-600 BC. In: DEGER-JALKTZY, S.; LEMOS, I. S. (Org.) Ancient Greece: from the Mycenaean palaces to the age of Homer. Edinburgh: Edinburgh University Press, 2006, p. 363-79.

VIDAL-NAQUET, Pierre. Valeurs religieuses et mythiques de la terre et du sacrifice dans l'Odyssée. Annales: Économies, Sociétés, Civilisations. 1970. Vol. 25, p. 1278-1297.

VILLATE, Sylvie. L'insularité dans la pensée grecque. (PDF. Introduction.) Presses Univ. Franche-Comté. 1991. 
WOODBURY, Leonard. Helen and the Palinode. Phoenix, Vol. 21, No. 3 (Autumn, 1967), p. 157-76. 